\title{
COMPETITIVENESS IN THE EXPORT DEMAND FOR NIGERIAN RUBBER
}

\author{
I. N. Nwachukwu' 1 , C. E. Onyenweaku², J. C. Nwaru ${ }^{2}$, J. A. Mbanasor ${ }^{1}$ and A. Daramola ${ }^{3}$
}

\begin{abstract}
The study examined the degree of competitiveness in the export demand for Nigerian rubber with focus on the Spanish Market. The study covered the periods of 1961 - 2010 and data comprised national aggregates. Two Stage Least Squares (2SLS) approach was used in the estimation after instrumenting for simultaneity and establishing stationarity cum cointegration relationship. The outcome of the analysis showed that the demand for Nigerian rubber by Spain was affected negatively by export price of the commodity and income of the importing country. The coefficients of export price of the substitute crop and world production excluding participating countries traced out a positive relationship. The result further showed that there is relative competitiveness in the Spanish market on the strength of the Lerner index of 0.015. The study recommends the allocation of more resources to the export crop through deliberate budgetary allocation to the producing states and exchange rate stabilization policies are strongly advocated among others
\end{abstract}

Keywords: Competitiveness, Export Demand, Nigerian rubber, Spanish market

\section{INTRODUCTION}

Agricultural commodity trade has played a prominent role in Nigeria's economic development. Drawing its strength from the largest sector (agriculture), such important roles include contribution to employment, food production, foreign exchange and industrial inputs (Omonona et al, 2007; Daramola et al, 2007). Nigeria's agricultural commodity exports can be categorized into namely traditional and non - traditional agricultural commodities. The prominent traditional export commodities include cocoa, palm oil, palm kernel, rubber, cotton, groundnut, kola nut among others while the non - traditional export commodities include pineapple, cashew, eggs, processed fruits, alcoholic beverages to mention but a few which have emerged as the most demanded products in the international markets (UNIDO, 1992).

Among the agricultural commodity exports, rubber is one of the most dominant crops in the export basket of Nigeria. Natural rubber is a vital agricultural commodity used in the manufacture of a wide range of products. Its production from the rubber tree (Hevea brasillensis) plays a major role in the socioeconomic fabric of many developing countries. Over 20 million families are dependent on rubber cultivation for their basic income in the world natural rubber market (Aye Aye, 2008). About $48 \%$ of the global demand for natural rubber comes from China, India and Malaysia which are three major natural rubber

\footnotetext{
1 Dept of Agribusiness and Management, Michael Okpara University of Agriculture, Umudike, Abia State, 1 Nigeria.

2 Dept of Agricultural Economics, Michael Okpara University of Agriculture, Umudike, Abia State, Nigeria

3 Dept of Agricultural Economics, Federal University of Technology, Akure, Ondo State, Nigeria
} 
consuming countries within the ANRPC (Association of Natural Rubber Producing Countries). However, the major buyers of rubber from Nigeria include Canada, France, China, Netherlands, Italy, Germany, Malaysia, South Africa, Spain and United Kingdom (Ayemibo, 2010). Nigeria is ranked second in Africa and about eleventh among exporters of rubber in the world (Figure 01).

The European market for natural rubber (NR), to which Spain belongs, has been experiencing price increases and volatility in recent times. Since 2008, natural rubber market evolutions have been huge, quick and apparently not always related to the traditional supplydemand scheme. Prices evolved from $1.2 \$ / \mathrm{kg}$ in February 2009 to $6.4 \$ / \mathrm{kg}$ in February 2011. The EU is import dependent on natural rubber, due to geographical and climatologic reasons there is no domestic production of natural rubber. Moreover, natural rubber production is concentrated in South East Asia (93\%) while the remaining is supplied by Africa. Out of 10, 291, 000 tonnes of natural rubber produced in the world in 2010, EU consumed $1,120,000$ tonnes representing $11 \%$ of the world production (ETRMA, 2011). Based on FAO (2009), Spain has stood out, over the years, as one of Nigeria's consistent trading partners and imports about $7.7 \%$ of the total agricultural exports from Nigeria.

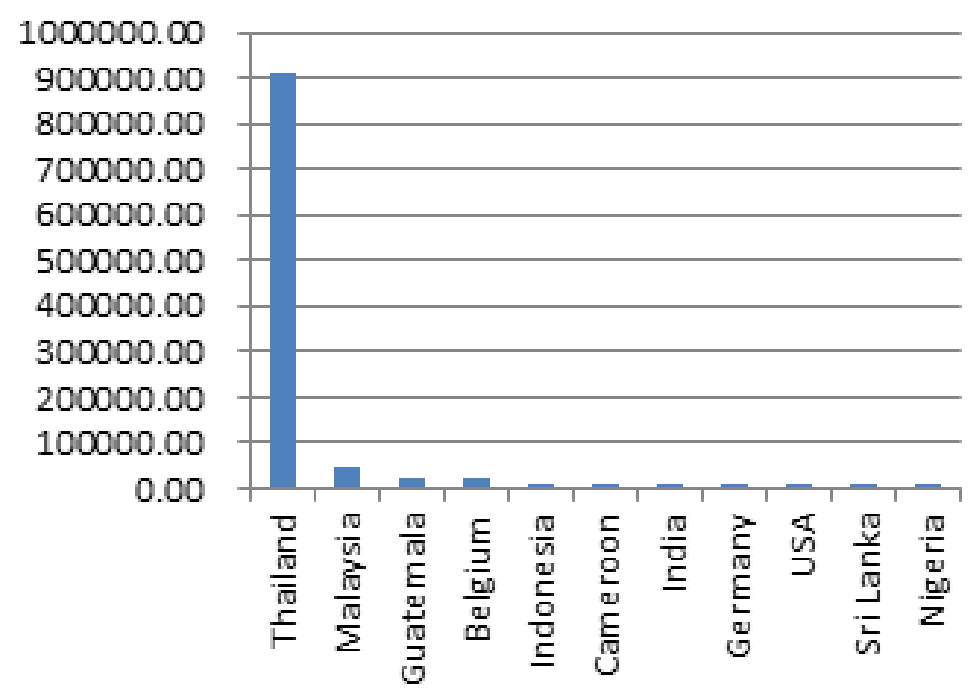

Figure 01: Major Exporters of Rubber in the World
In Nigeria, Rubber is currently grown in Edo, Delta, Ondo, Ogun, Abia, Anambra, Akwa Ibom, Cross River, Rivers, Ebonyi and Bayelsa States where the amount of rainfall is about $1800 \mathrm{~mm}$ to $2000 \mathrm{~mm}$ per annum. In terms of price, the FOB prices range from USD2,5003,000/MT depending on quality and time of year (Ayemibo, 2010).

It has also been observed that those unfavorable domestic terms of trade for agricultural exports, loss of market power and declining output are the principal contributors to the dismal performance of traditional exports, and those factors reflect in the interaction of inappropriate domestic pricing policies and external shocks. It is hoped that the outcome of this study will form a formidable basis for formulating appropriate sub - sectoral policies and dependable platform for taking informed decisions cum act as a reference to further studies. As such, wider interest will be stimulated in this study area and attention drawn to the need for redefining, revitalizing and re-diversifying Nigeria's economic prosperity. On the basis of the foregoing, the study aimed to estimate export demand of Nigerian rubber to the Spanish market; to measure the market power of Nigeria in the export of Rubber to Spain.

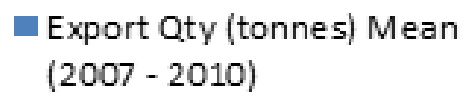

Export Qty (tonnes) Mean $(2007-2010)$ 


\section{Theoretical Framework}

Assuming an industry consisting of n-firms produces a homogenous output with identical costs faces market demand given by the following:

$\mathrm{Q}_{\mathrm{t}}=Q\left(P_{t}, z_{t}\right)$

where $\mathrm{Q}$, is the total quantity demanded, $P_{\mathrm{t}}$ is the market price, $Z_{t}$ is a vector of exogenous variables such as the prices of substitutes and income, and $t$ is a time subscript (Bresnahan (1989); Perloff (1992); Susanto (2006).

Since $Q$, and $P$, are determined simultaneously, the demand function can also be written in inverse form, $P_{\mathrm{t}}=P\left(Q_{\vec{p}} Z\right)$. Suppose also that the aggregate marginal cost facing the industry is given by

$$
M C_{p}=M C\left(Q_{t}, W_{t}\right)
$$

where $W_{t}$ is a vector of exogenous variables such as input costs.

Assuming that the industry is perfectly competitive, equilibrium price and quantity will be determined by

$P_{t}=P\left(Q_{t} Z_{t}\right)=M C_{t}=M C\left(Q_{t} W_{t}\right)$

More generally, if the industry is imperfectly competitive, equilibrium is where perceived industry marginal revenue equals industry marginal cost. If industry revenue is defined as $R_{t}=P Q_{t}=P\left(Q_{t}, Z\right) Q$, the equilibrium condition can be rewritten as:

$M R(\lambda)=\left[P\left(Q_{t}, Z,\right)+d P / d Q_{t}\left(Q_{t} Z_{l}\right) Q_{t}\right]=$ $M C\left(Q_{i}, W\right)$.

$\lambda$ can be interpreted as an index of market power being exerted in an industry, that is, the wedge, in equilibrium, between industry price and industry marginal cost (Bresnahan, 1982). The value of $\lambda$ falls in the range $0 \leq \lambda$ $\leq 1$; if the industry is perfectly competitive, the parameter $\lambda=0$, and (4) becomes the usual condition that price equals marginal cost.
If the industry is either a monopoly or firms demonstrate perfectly collusive behavior, $\lambda$ $=1$, and (4) becomes the normal expression for a monopoly markup. Intermediate values of $\lambda$ reflect oligopolistic outcomes where the markup over marginal cost is less than the monopoly mark-up; for example, $\lambda$ will take the value $1 / n$ if the $n$ firms in the market behave in Cournot-Nash fashion. The reason for the Cournot-Nash value of $\lambda=l / n$ becomes apparent once a connection is made between the market power parameter $\lambda$ and the concept of conjectural variations.

This connection is illustrated briefly here using a simple duopoly model. Let firm 1 expect firm 2 to produce $\mathrm{q}_{2}$ units of output. If firm 1 produces $\mathrm{q}_{1}$ units of output, the total output it expects to be sold in the market is $Q=q,+q$ . The profit maximizing problem for firm 1 is then:

$\max q_{l}\left\{P(Q) q_{l}-c_{l}\left(q_{l}\right)\right\}$

where $P(Q)$ is the inverse demand function, and $c_{l}\left(q_{l}\right)$ is firm l's total cost function.

Differentiating (5) with respect to $\mathrm{q}_{1}$, and after some manipulation, the first-order condition is

$P(Q)+d P / d Q\left[1+d q_{2} / d q_{1}\right] \mathrm{q}_{1}+M C_{1}\left(q_{l}\right)$

where $M C_{l}($.$) is firm 1's marginal cost, \mathrm{q}_{2}$ is the equilibrium value of $q_{2}^{e}$, and $d q_{2} / d q$, is the conjectural variations term. It summarizes how firm 1 conjectures firm 2 will vary its output when firm 1 makes a small change in output. Denote this term as $\mathrm{u}$ if the firms are symmetric, that is, they have identical costs and, therefore, produce the same level of output, then equation (6) can be generalized to $n$ firms as:

$P(Q)+d P / d Q[1+(\mathrm{n}-1) \mathrm{v} / \mathrm{n}] \mathrm{Q}=M C$

Recall equation (4) and compare with (7). These two are identical equations, where the 
index of market power is defined as $\lambda=[1+$ $(n-1) v] / n$. It is obvious that if firms behave in Cournot-Nash fashion, that is, $v=0$, then the corresponding value of $\lambda$ is $l / n$. Hence, $\lambda$ is interpreted as an index of the degree of market power, in which is nested a conjectural variations parameter.

In order to identify $\lambda$ in an econometric model, the method employed in Susanto (2006); Nwachukwu (2009) is adapted. The export demand function in (1) is specified in the following form:

$$
\mathrm{Q}_{\mathrm{i}}=\alpha_{0}+\alpha_{1} \mathrm{P}_{\text {it }}+\alpha_{2} \mathrm{P}_{\text {st }}+\alpha_{3} \mathrm{I}_{\mathrm{t}}+\alpha_{4} \mathrm{P}_{\mathrm{it}} \mathrm{I}_{\text {it }}+\alpha_{5} \mathrm{~W}_{\text {it }}+\varepsilon_{\mathrm{it}} \ldots \ldots
$$

where $Q$, is the quantity of commodity sold in the export market, $P_{t}$ is the real price of commodity, other exogenous variables include $\mathrm{I}_{\mathrm{t}}$ is the income of the destination country, $\mathrm{P}_{\mathrm{it}} \mathrm{I}_{\text {it }}$ is the interaction term between $\mathrm{P}_{\mathrm{it}}$ and $\mathrm{I}_{\mathrm{it}}, \mathrm{W}_{\mathrm{t}}$ is the total production of non - participants in the destination market and $\varepsilon_{i t}$ is the error term. This form of demand function, used in earlier studies by Buschena and Perloff (1991); Love and Murniningtyas (1992), is linear in coefficients but contains the interactive term $P_{i t} I_{i t}$

Following Bresnahan (1989) and Buschena and Perloff (1991), suppose that the aggregate marginal cost of production takes the following functional form:

$$
M C_{t}=\varnothing_{\mathrm{b}} \mathrm{V}_{\mathrm{t}}+\varnothing_{\mathrm{c}} \mathrm{C}_{\mathrm{t}}+\eta_{\mathrm{it}}
$$

Marginal cost is assumed to be a function of variable inputs and Ocean Freight Rate denoted with $V_{t}$ and $C_{t}$ respectively.

Equation (9) can now be substituted into the profit-maximizing condition (4). Rearranging terms, the following equation known as the optimality equation (supply relation) is derived:

$\mathrm{P}_{\mathrm{it}}=\varnothing_{0}+\varnothing_{\mathrm{a}} \mathrm{Q}_{\mathrm{it}}+\varnothing_{\mathrm{b}} \mathrm{V}_{\mathrm{t}}+\varnothing_{\mathrm{c}} \mathrm{C}_{\mathrm{t}}+,\left[\frac{\mathrm{Q}_{\mathrm{it}}}{\overline{\alpha_{1}+\alpha_{4} \mathrm{I}_{\mathrm{t}}}}\right]+\eta_{\mathrm{it}}(10)$
Equation (10) is an equilibrium condition where perceived marginal revenue equals marginal cost. All variables are as previously defined while $\lambda$ and $\eta_{\text {it }}$ represent the index of competitiveness (market power) and error term respectively. Note that the interactive term adds some nonlinearity to the demand function so that $\lambda$ can be identified. If $\mathrm{W}_{\mathrm{it}}$ changes, the demand curve will rotate around the equilibrium point and trace out the supply relation, which allows the ease of calculating the degree of competitiveness.

\section{Data Sources}

Data used by the study were national aggregates obtained from secondary sources. They covered the periods $1961-2010$ and were mainly from the several issues of the Production Yearbook published by the Food and Agriculture Organization (FAO), FAOSTAT website, the National Bureau of Statistics (NBS) Annual Abstract of Statistics and several issues of the Central Bank of Nigeria's (CBN) Annual Reports and Statement of Accounts, United Nations and World Bank databases.

\section{Model Specification and Data Analysis}

To estimate the degree of export competitiveness (market power), equations (8) and (10) are operationalized. The export demand function is specified thus:

$\mathrm{Q}_{\mathrm{t}}=\alpha_{0}+\alpha_{1} \mathrm{P}_{\mathrm{t}}+\alpha_{2} \mathrm{P}_{\mathrm{st}}+\alpha_{3} \mathrm{I}_{\mathrm{t}}+\alpha_{4} \mathrm{PI}_{\mathrm{t}}+\alpha_{5} \mathrm{~W}_{\mathrm{t}}+\varepsilon_{\mathrm{t}} \ldots$ (11

Where $Q_{t}=$ the quantity of Nigerian rubber to Spain

$P_{t}=$ Real export price of the crop

$\mathrm{P}_{\text {st }}=$ Real export price of substitute crop (gums) in the Spanish market

$I_{t}=$ Income proxied by the GDP of Spain

$\mathrm{PI}_{\mathrm{t}}=$ The interaction term, which is the product of $\mathrm{P}_{\text {st }}$ and $\mathrm{I}_{\mathrm{t}}$. 
$\mathrm{W}_{\mathrm{t}}=$ Total production of the export crop excluding participating countries in the rubber Spanish market

$$
\begin{aligned}
& \alpha_{; s}=\text { Parameters to be estimated } \\
& \varepsilon_{\mathrm{t}}=\text { Error term }
\end{aligned}
$$

The supply relation (Optimality equation) is also operationalized in line with equation (10) and stated thus:

$\mathrm{P}_{\mathrm{t}}=\varnothing_{0}+\varnothing_{\mathrm{a}} \mathrm{Q}_{\mathrm{t}}+\varnothing_{\mathrm{b}} \mathrm{V}_{\mathrm{t}}+\varnothing_{\mathrm{c}} \mathrm{C}_{\mathrm{t}}+\left[\frac{\mathrm{Q}_{\mathrm{t}}}{\overline{\alpha_{1}+\alpha_{4} \mathrm{I}_{\mathrm{t}}}}\right]+\eta_{\mathrm{t}} \cdot($

Where:

$\mathrm{V}_{\mathrm{t}}=$ Variable cost of producing the export crop proxied by a ratio of the producer price (in local currency) to a measure of the domestic price. This models the cost of production

\section{$\mathrm{C}_{\mathrm{t}}=$ Ocean freight rate represents a cost to exporters}

The proxy was employed in line with Gbetnkom and Khan (2002) due to data unavailability.

All variables are as previously defined and $\lambda$ is an index of market power (competitiveness).

On the basis of theory, $\mathrm{Q}_{\mathrm{i}}$ is observed to be endogenous and has to be instrumented if statistical test indicates potential simultaneity between $\mathrm{Q}_{\mathrm{t}}$ and $\mathrm{P}_{\mathrm{t}}$

Since the own quantity $Q_{t}$ in equations (11) and (12) is potentially endogenous because of the simultaneous relationship with own price, $\mathrm{P}_{t}$, Hausman specification test was implemented following the reduced form equation employed to obtain an instrumental variable.

$\mathrm{Q}_{\mathrm{t}}=\beta_{\mathrm{n}} \mathrm{IV}+\varepsilon_{\mathrm{i}}$

Where:

IV denotes instrumental variables - a vector of exogenous or predetermined variables which are strongly correlated with $Q_{t}$ but not correlated with the error term.

$\beta_{\mathrm{n}}=$ Vector of coefficients to be estimated

$\varepsilon_{\mathrm{it}}=$ Error term

The IV includes all the exogenous variables in the demand and optimality equations.

The instrumented demand and optimality equations are thus:

$\mathrm{Q}_{\mathrm{t}}=\alpha_{0}+\alpha_{1} \mathrm{P}_{\mathrm{t}}+\alpha_{2} \mathrm{P}_{\mathrm{st}}+\alpha_{3} \mathrm{I}_{\mathrm{t}}+\alpha_{4} \mathrm{PI}_{\mathrm{t}}+\alpha_{5} \mathrm{~W}_{\mathrm{t}}+\varepsilon_{\mathrm{t}}$

$\left.\mathrm{P}_{\mathrm{t}}=\varnothing_{0}+\varnothing_{\mathrm{a}} \mathrm{Q}_{\mathrm{t}}+\varnothing_{\mathrm{b}} \mathrm{V}_{\mathrm{t}}+\varnothing_{\mathrm{c}} \mathrm{C}_{\mathrm{t}}+: \frac{\mathrm{Q}_{\mathrm{t}}}{\alpha_{1}+\alpha_{4} \mathrm{I}_{\mathrm{t}}}\right]+\eta_{\mathrm{t}}$.

From the simultaneous equations above, the endogenous variables are:

$\mathrm{Q}_{\mathrm{t}}=$ the quantity of export crop to destination country $\mathrm{i}$

$\mathrm{P}_{\mathrm{t}}=$ Real Export Price of the crop (instrumented)

The pre - determined variables are:

$\mathrm{P}_{\mathrm{st}}=$ Real export price of substitute crop in the destination country

$I_{t}=$ Income proxied by the GDP of the destination country

$\mathrm{PI}_{t}=$ The interaction term, which is the product of $\mathrm{P}_{\text {st }}$ and $\mathrm{I}_{\mathrm{it}}$.

$\mathrm{W}_{\mathrm{t}}=$ Total production of the export crop excluding participating countries in the destination market.

$\mathrm{V}_{\mathrm{t}}=$ Variable cost of producing the export crop proxied by the ratio of producer price to the domestic price

$\mathrm{C}_{\mathrm{t}}=$ Ocean freight rates represent cost to exporters

$\lambda=$ Market power index

The model is over identified and thus was estimated with two - stage least squares (2SLS) given its simultaneous equation 
posture. The approach (order condition) for solving the identification problem followed Koutsoyiannis (1977) and Thomas (2007) who averred that if the equality sign is satisfied, that is if $(\mathrm{K}-\mathrm{M})=(\mathrm{G}-1)$, the equation is exactly identified. If the inequality sign holds, that is, if $(\mathrm{K}-\mathrm{M})>(\mathrm{G}-1)$, the equation is over identified.

Where:

$\mathrm{G}=$ total number of equations (= total number of endogenous variables).

$\mathrm{K}=$ number of total variables in the model (endogenous and predetermined)

$\mathrm{M}=$ number of variables, endogenous and exogenous, included in a particular equation.

In line with time series estimation, the variables were subjected to stationarity and cointegration before two stage least squares (2SLS) estimation was employed to address the simultaneous equation relationship.

To obtain the price elasticity as well as income elasticity, the following was applied:

$\varepsilon_{\mathrm{p}}=\left(\theta_{\mathrm{p}}+\theta_{\mathrm{pI}} \overline{\mathrm{I}}\right)(\overline{\mathrm{P}} / \overline{\mathrm{Q}})$

and the income elasticity given as

$\varepsilon_{\mathrm{I}}=\left(\theta_{\mathrm{I}}+\theta_{\mathrm{pI}} \overline{\mathrm{P}}\right)(\overline{\mathrm{I}} / \overline{\mathrm{Q}})$

The lerner index is stated thus:

$\mathrm{L}=\underline{\mathrm{P}-\mathrm{MC}}=\underline{-\lambda \mathrm{Q}_{\underline{t}}}\left(\partial \mathrm{P}_{\underline{t}}(.) / \partial \underline{\mathrm{Q}}_{\underline{\underline{t}}}\right)=\underline{\lambda}$

$\mathrm{P} \quad \mathrm{P}$

\section{RESULTS AND DISCUSSION}

During the study period, the total export quantity of rubber had a mean of $48,047.70$ tonnes with a corresponding standard deviation of 22,319.09 tonnes as shown by the summary statistics in Table 01. The gap between the minimum and maximum values was quite large, which implied that there had been tremendous increase in the export volumes during the period of study. Similar increases were also recorded in the quantities exported to Spain during the period. In general, there had been an upward trend in the export of rubber to Spain over time. The export prices showed similar upward trend during the sample period. The difference between the minimum and maximum prices for rubber was $\$ 1.038 .59$ per tonne depicting 121.58 percent rise. Probably, increase in price may have contributed to increase in the quantity exported in line with theory. Furthermore, the price of substitutes (gums) rose tremendously. The large values of the standard deviation try to show the existence of variability over the years. The gross domestic product (GDP) showed an upward trend as revealed by the difference between the minimum and maximum values. This reflected enhanced prosperity of the importing country.

The variables for both the demand function and supply relation of rubber exports were subjected to stationarity and cointegration tests in line with time series econometrics and their results presented in Table 02 and Table 03 respectively. It could be observed in Table 02 that all the variables that were subjected to the ADF unit root test were not stationary in their level form at all levels of significance. On application of the ADF test on their first difference terms after logging, they became stationary as shown by the values of the ADF test, which are larger (in absolute terms) than the standard critical values.

To also confirm stationarity, the variables were also subjected to PP test which was believed to give robust estimates. All the variables became stationary in their first difference terms. Hence, they are integrated of order one, 1(1). The cointegration test was preceded by the performance of ordinary least squares (OLS) estimation on the variables in 
levels. The residuals generated from the OLS demand function and supply relation for both estimation were subjected to the cointegration export commodities are presented in Table 04 . test. The results of the cointegration test for

Table 01: Summary Statistics of the Data

\begin{tabular}{lllll}
\hline Variable & Mean & Minimum & Maximum & Std. Dev \\
Rubber & & & & \\
Export quantity (tonnes) & 48047.70 & 14575.00 & 113028.00 & 22319.09 \\
Export value (\$000) & 39914.66 & 11173.00 & 155000.00 & 31063.65 \\
Export quantity to Spain (t) & 6831.27 & 784.00 & 19489.00 & 3928.17 \\
Export price (\$/000) & 854.27 & 271.44 & 1892.86 & 423.59 \\
Export price of substitute (\$) & 3352.79 & 557.33 & 27000.00 & 5852.17 \\
Producer price (N) & 64263.75 & 1395.33 & 207750.50 & 61604.03 \\
World Prod. less & & & & \\
Participating Countries (t) & 1363296.95 & 393009.00 & 7251424.00 & 1425507.64 \\
GDP of importing & & & & \\
country (\$b) & 362.40 & 13.83 & 1437.91 & 356.38 \\
Value of Agric. Export & 12938340.15 & 471901.00 & 6605000.00 & 13295894.01 \\
Value of World Agric. Export & 3.20 & 0.14 & 14.00 & 3.31 \\
Real Exchange rate & 74.50 & 0.02 & 201.00 & 72.26 \\
Annual average rainfall (mm) & 1295.81 & 897.00 & 1597.00 & 172.05 \\
& & & &
\end{tabular}

Table 02: Augmented Dickey-Fuller (ADF) and Phillips-Perron (PP) Tests for Integration Order

\begin{tabular}{llccc}
\hline Variable & \multicolumn{2}{c}{ ADF } & \multicolumn{2}{c}{$\mathrm{PP}$} \\
\hline & $1(0)$ & $1(1)$ & $1(0)$ & $1(1)$ \\
\hline $\mathrm{Q}_{\mathrm{t}}:$ Rubber & -3.008 & -4.665 & -3.068 & -4.663 \\
$\mathrm{P}_{\mathrm{t}}:$ Rubber & -3.035 & -4.463 & -3.035 & -4.314 \\
$\mathrm{P}_{\mathrm{st}}:$ Rubber & -2.404 & -4.511 & -3.004 & -4.514 \\
$\mathrm{I}_{\mathrm{t}}:$ Rubber & -3.189 & -4.197 & -3.086 & -4.567 \\
$\mathrm{P}_{\mathrm{t}}:$ Rubber & -3.102 & -5.835 & -3.167 & -4.301 \\
$\mathrm{~W}_{\mathrm{t}}:$ Rubber & -3.191 & -4.722 & -3.191 & -6.697 \\
$\mathrm{C}_{\mathrm{t}}:$ Rubber & -3.087 & -4.861 & -3.111 & -4.201 \\
$\mathrm{~V}_{\mathrm{t}}:$ Rubber & -2.971 & -4.962 & -3.080 & -4.199 \\
\hline
\end{tabular}

NB: Critical values of ADF at $1 \%(* * *), 5 \%(* *)$ and $10 \%(*)$ are $-4.196,-3.520$ and -3.192 respectively. The PP test critical values at $1 \%(* * *), 5 \%(* *)$ and $10 \%(*)$ are $-4.187,-3.516$ and -3.190 respectively. 
Table 03: Results of Residual Based Cointegration Test

\begin{tabular}{lll}
\hline Crop & ADF & PP \\
\hline $\begin{array}{l}\text { Demand Function } \\
\text { Rubber } \\
\begin{array}{l}\text { Supply Relation } \\
\text { Rubber }\end{array}\end{array}$ & $-3.234 * * *$ & $-3.234 * * *$ \\
& $-5.844 * * *$ & $-5.844 * * *$ \\
\hline
\end{tabular}

NB: Critical values of ADF at $1 \%(* * *), 5 \%(* *)$ and $10 \%(*)$ are $-2.641,-1.950$ and -1.607 respectively.

Table 04: Results of Simultaneity Test

\begin{tabular}{lccr}
\hline Export Crop & Destination Country & Test Statistics & Simultaneity \\
\hline Cocoa & Netherlands & $2.307^{* *}$ & Yes \\
Rubber & Spain & $14.604^{* * *}$ & Yes \\
\hline
\end{tabular}

The result of the residual based cointegration test showed that the regression residuals of both the demand function and supply relation were stationary. Both the ADF and PP tests were applied but the critical values of the latter were relied upon. Dittmann (2002) argued that Phillips-Perron test when applied to residual based cointegration determination is more powerful than the ADF test. Based on the critical values, it could be inferred that there exists a cointegration relationship in both demand function and supply relation equations.

Prior to estimation and given that own quantity was potentially endogenous because of the presence of simultaneous relationship with own price, Hausman specification test was performed and the result shown in Table 04. It could be observed that there is simultaneity since the results are significant and the null hypothesis of no simultaneity between $\mathrm{P}_{\mathrm{it}}$ and $\mathrm{Q}_{\mathrm{it}}$ rejected at 5\% and 1\% levels of probability.

Having found that the model is over identified after the simultaneity test, the two stage least squares (2SLS) method was applied in order to realize unbiased and consistent estimates and the results presented in Table 05. The demand for rubber by Spain (Nigeria's trading partner) was affected negatively by export price of the commodity and income of the importing country. By implication, any $10 \%$ increase in the quantity demanded by the importing country (Spain) is influenced by $10.22 \%$ and $10.99 \%$ reduction in export price of the commodity and income of the country respectively. Although the negative relationship between demand and price is in line with a priori expectation, that of demand and income of the importing country is uncommon. It is likely that rubber is a necessity in Spain and thus, changes in the income of the importing country did not influence demand.

The coefficients of export price of the substitute crop and world production excluding participating countries had positive signs. The positive sign possessed by the export price of the substitute crop (gums) is in line with a priori expectation.

In the supply relation, export quantity had a negative coefficient while the ocean freight rate possessed a positive coefficient. This indicates that marginal cost increases as export quantity increases while ocean freight decreases.

The market power coefficient (-0.419) was negative and statistically different from zero at 5\% level of probability. Applying 
the Lerner index which gave 0.015 implies that the Spanish export market for rubber is competitive. According to De Wulf (2004), a good is competitive if it can coexist with imports where domestic production is not sufficient to satisfy the domestic market, and can be exported when it is in surplus supply. In case it is not competitive, the commodity needs to be protected against imports to let production take place at all in the country, and the commodity cannot be exported. Given that market power is interpreted as an index of degree of competitiveness of the industry, it could be inferred that Nigeria has competitive advantage in the export of rubber to the Spanish market.

Table 05: Estimation of Market Power of Rubber Export in the Spanish Market using 2SLS

\begin{tabular}{|c|c|}
\hline Variable & Coefficients \\
\hline \multicolumn{2}{|l|}{ Export Demand } \\
\hline Intercept & $\begin{array}{l}13.345 \\
(1.008)\end{array}$ \\
\hline Real export price & $\begin{array}{l}-1.022 \\
(-2.056)\end{array}$ \\
\hline Real export price of substitute & $\begin{array}{l}0.421 * * * \\
(3.082)\end{array}$ \\
\hline GDP of destination market & $\begin{array}{l}-1.099 * * * \\
(-3.553)\end{array}$ \\
\hline Interaction term & $\begin{array}{l}0.642 \\
(1.264)\end{array}$ \\
\hline World prod. less market participants & $\begin{array}{l}0.608 * * * \\
(2.530)\end{array}$ \\
\hline $\mathrm{R}^{2}$ & 0.509 \\
\hline $\begin{array}{l}\text { F - Ratio } \\
\text { Supply Relation }\end{array}$ & 6.854 \\
\hline Export quantity & $\begin{array}{l}-0.697 * * * \\
(-3.282)\end{array}$ \\
\hline Variable cost of production & $\begin{array}{l}0.084 \\
(0.209)\end{array}$ \\
\hline $\begin{array}{l}\text { Ocean Freight Rate proxied by } \\
\text { Cost of export }\end{array}$ & $\begin{array}{l}0.489 * * \\
(2.274)\end{array}$ \\
\hline$\lambda$ & $\begin{array}{l}-0.419 \\
(-2.367)\end{array}$ \\
\hline $\mathrm{R}^{2}$ & 0.685 \\
\hline F - Ratio & $\begin{array}{l}15.312 \\
(4.151)\end{array}$ \\
\hline DW & 2.32 \\
\hline
\end{tabular}

NB: Figures in parentheses are t-test Values

$* * *, * *$ and $*$ represent significance at $1 \%, 5 \%$ and $10 \%$ probability levels respectively. 
In terms of the diagnostic statistics, the demand function and supply relation of the export crop have appreciable $\mathrm{R}^{2}$ estimates and $\mathrm{F}$ - ratios, implying reasonable explanation of variations in the quantity demanded and overall significance of the model respectively. The DW estimates showed absence of autocorrelation in the model given that they fell within $1.5-2.5$ range.

\section{CONCLUSION}

Agricultural export plays an important role in the economic development of any nation. The extent to which this level of progress is attained and sustained depends heavily on the level of export capacity and competitive power in target markets. It is glaring from the findings of the study that specific attention should be paid to rising production and export costs among others if the observed increase in the output volume and demand of the spanish is to be sustained.

Although Nigeria has a relatively high market power in the Spanish market, deliberate efforts should be made to sustain such a lofty competitive status. Hence, government intervention is necessary in the area of input/production subsidies, targeted export promotion programs, farm settlement, expanded export processing zones (value addition). Subsequently, there should be special revenue allocation/derivation formula for dominant rubber producing zones as a form of incentive and motivation for expanding production.

\section{REFERENCES}

Aye Aye, K., C.F.C. Eddie, N.S. Mad and A.M. Zainal (2008). Natural Rubber Price Forecasting in the World Market. A Paper presented at'AGREX08' with the theme, "Agriculture Sustainability through Participative Global Extension" held at Equatorial Hotel Banji Putrajaya on $15^{\text {th }}-18^{\text {th }}$ June, Malaysia.

Ayemibo, B. (2010). Exporting from Nigeria: Cocoa Beans. A Certified Documentary Credit Specialist (CDCS) Tutorial. www.linkedin.com/in/bayemibo. Accessed 28/2/2011

Bresnahan, T.F. (1989). Empirical Studies of Industries with Market Power, In: Handbook of Industrial Organization. R. Schmalensee and R. Willig (eds) Vol. II, Chapter 17,Amsterdam, North Holland.

Bresnahan, T.F. (1982). The Oligopoly Solution Concept is Identified. Economic Letters 10(1): 87-92. http://dx.doi.org/10.1016/0165-1765(82)90121-5

Buschena, D. E. and J. M. Perloff (1991). The Creation of Dominant Firm Market Power in the Coconut Oil Export Market. American Journal of Agricultural Economics, November 1991: 1000-1008.

Daramola, A., S. Ehui, E. Ukeje, and J. McIntire. (2007). Agricultural Export Potential: In Collier P. and C. Pattillo (eds.), Economic Policy Options for a Prosperous Nigeria, London: Palgrave Macmillan.

De Wulf, L. (2004). Globalization and International Competitiveness: Concepts and Policy Implications for Agriculture, In: Report of the Asian Productivity Organization (APO) Study Meeting on Agricultural Diversification and International Competitiveness, Tokyo, 16 - 23 May. 
Dittmann, I. (2002). Residual Based Tests for Fractional Cointegration: A Monte Carlo Study. Journal of Time Series Analysis, 21(6): 615 -647.

European Tyre and Rubber Manufacturers' Association (ETRMA) (2011). An Effective and Delivery Raw Materials Policy: A Cornerstone for Industry Competitiveness and the EU Resource - Efficiency Target. A Position Paper by European Tyre and Rubber Manufacturers' Association (ETRMA). http://www.etrma.org.

Food and Agriculture Organization (FAO) (2009). Statistical Yearbook. A Publication of FAO, Rome.

Gbetnkom, D. and S. A. Khan (2002). Determinants of Agricultural Exports: The Case of Cameroon. AERC Research Paper 120, AERC, Nairobi, Kenya.

Koutsoyiannis, A. (1977). Theory of Econometrics, $2^{\text {nd }}$ Edition, Palgrave Publishers, New York.

Love, H. A. and E. Murniningtyas (1992). Measuring the Degree of Market Power Exerted by Government Trade Agencies. American Journal of Agricultural Economics 74(1): 546555 .

Nwachukwu, I.N. (2009). Market Power and Agricultural Export Performance of Nigeria. A Ph.D Proposal Presented to the Department of Agricultural Economics, Michael Okpara University of Agriculture, Umudike, Abia State, Nigeria

Omonona, B. T., O. A. Oni and E. Akpan (2007). The Determinants of Demand for Nigeria's Agricultural Export Commodities. Pakistan Journal of Social Sciences. 4(2): 247 - 251.

Perloff, J. M. (1992). Econometric Analysis of Imperfect Competition and Implications for Trade Research. In: Proceedings of a Workshop on Industrial Organization and International Trade (eds) I. M. Sheldon and D. R. Henderson, NC-194 Research Monograph Number 1, Ohio State University, Columbus, USA.

Susanto, D. (2006). Measuring the Degree of Market Power in the Export Demand for Soybean Complex. Ph.D Thesis, Department of Agricultural Economics and Agribusiness, The Louisiana State University, USA.

Thomas, A. (2007). Econometrics, Andren and Ventus Publishing APS, USA.

United Nations Industrial Development Organization (UNIDO) (1992). Report of the Export Group Meeting on the Implication of the single European Market for Industrialization in Developing Countries. March ID/WG 253/8 